https://doi.org/10.31470/2706-7904-2020-15-297-302

\title{
LINGUISTIC SEMANTICS OF THE COVID-19 QUARANTINE IDEATION
}

Мовна семантика уявлень щцоо коронавірусного карантину

\author{
Vitalii Shymko \\ DSc. in Psychology, Professor \\ Pereiaslav-Khmelnytskyi Hryhorii Skovoroda State Pedagogical University (Ukraine) \\ shymko@outlook.com \\ https://orcid.org/0000-0003-4937-6976
}

\begin{abstract}
The manuscript presents a summary of the results of the linguistic semantics study of Covid-19 related quarantine. Research conducted on a sample of Russian speaking Ukrainians. Found content and structure of the respective discursive field. Described features of inter-discourse connections. Established that the actualization of some discourses is accompanied by the deactivation of others, what makes quarantine semantics biased. Also, it was suggested that some of the discourses are indirectly positively associated and form the semantic core of the quarantine concept.
\end{abstract}

Key words: quarantine, Covid-19, coronavirus, discourse, linguistic semantics.

\section{Introduction}

Efficient implementation of quarantine involves behavioral, organizational, informational, value and other factors synchronization of the actions by millions of people. One of the formal quarantine definitions states it is' a restriction on the movement of people and goods which is intended to prevent the spread of disease or pests' (Quarantine, 2020). Obviously, human beings are barely guided by formal definitions, but rather their own ideas on the matter. To implement the mentioned synchronization, it is necessary to clarify semantic features of quarantine concept and how it perceived by specific individuals and groups of people.

\section{Methods and Techniques of the Research}

The corresponding attempt was implemented by us on a sample of Russian-speaking Ukrainians. The sample includes 104 participants (all of them with higher education; aged 
21 to 62 years; $47.1 \%$ of women) from several regions of Ukraine: Kyiv, Dnipro, Kharkiv, Odessa, Lviv, Rivne, Mukachevo. The study was conducted in the second half of May 2020, which means that all respondents spent more than 60 days under national quarantine conditions, started in Ukraine on March 11, 2020. Most of the respondents worked during the quarantine period, visiting offices and other places of professional activity. $13.5 \%$ were on short-term of self-isolations (from 1 to 15 days). One respondent self-isolated himself for 50, and two - for 56 days. Participants had been asked to set out their own understanding of quarantine, i.e. formulate an appropriate definition in written. Respondents also assessed how much their psychological well-being and everyday life routine had been changed during quarantine and shared some socio-demographic parameters in anonymous questionnaire 'My Quarantine', which along with statistical analysis results are publicly available at Harvard Dataverse (Shymko \& Babadzhanova, 2020).

The respondents' quarantine definitions were classified and quantified based on Foucault's theory of such a linguistic category as a discourse (Foucault, 1972: 107-108). Herewith the practical side of discourses identification in the texts studied was realized through recognizing stable semantic autonomies generated by dispersions of verbal meanings (Shymko, 2018). This work was carried by the experts (four scientists, practical researchers with more than 20 years of professional background in the field of applied psycholinguistics). At the first step, each expert independently analyzed every text and formed the initial classification of the identified discourses. Then these discourses were compiled together and in such a way a general list of 23 discourses was created. At the second step, the experts had discussed the general list, clarified the semantics of previously derived discourses and through terminological unification the list was reduced to nine positions. On the third step the hierarchical cluster analysis had been applied, the results of which substantiated the expediency of combining some of the discourses, that ultimately allowed us to distinguish seven discourses in the respective discursive field (Table 1).

Table 1. Discursive field of quarantine concept

\begin{tabular}{|l|l|l|}
\hline No & \multicolumn{1}{|c|}{ Discourse title } & \multicolumn{1}{|c|}{ Semantic content of discourses derived by experts } \\
\hline 1. & $\begin{array}{l}\text { CONTACT } \\
\text { RESTRICTION }\end{array}$ & $\begin{array}{l}\text { Restriction/control of contacts, meetings and movements as } \\
\text { contacts motivators, its amplifiers and intensifiers. Aspect of } \\
\text { forced passivity. }\end{array}$ \\
\hline 2. & $\begin{array}{l}\text { SANITATION AND } \\
\text { HYGIENE }\end{array}$ & $\begin{array}{l}\text { Sanitary and hygiene products and their use, preventive } \\
\text { measures. Quarantine behavior (awareness, caution, } \\
\text { discipline), including social distancing, remote work and self- } \\
\text { isolation. The internality aspect. Activity. }\end{array}$ \\
\hline
\end{tabular}




\begin{tabular}{|l|l|l|}
\hline 3. & $\begin{array}{l}\text { ISOLATION OF } \\
\text { INFECTED }\end{array}$ & $\begin{array}{l}\text { Isolation of infected and sick people, as well as those who } \\
\text { have been in contact with them (ones suspected of being } \\
\text { infected). Segregation aspect. }\end{array}$ \\
\hline 4. & VIRUS DISSEMINATION & $\begin{array}{l}\text { Prevention (restriction, control) of the spread of the virus } \\
\text { (disease). Socio-geographical aspect. Reducing the number of } \\
\text { infected people and/or patients. }\end{array}$ \\
\hline 5. & LIFESTYLE CHANGES & $\begin{array}{l}\text { Change in the habitual (everyday) way of life of people and } \\
\text { society overall (work, home life, entertainment, etc.). Not } \\
\text { specified limitations and restrictions of life activity. } \\
\text { Discomfort and frustration, as indicators of a reaction to a } \\
\text { violation of the regular lifestyle. }\end{array}$ \\
\hline 6. & $\begin{array}{l}\text { BUREAUCRATIC } \\
\text { RESPONSE }\end{array}$ & $\begin{array}{l}\text { The introduction of official standards and regulations by the } \\
\text { authorities. Socio-legal and medical-infrastructural aspects of } \\
\text { state (societal) regulation. Epidemic statistics and other } \\
\text { studies. Organization of public awareness (alert system). }\end{array}$ \\
\hline 7. & $\begin{array}{l}\text { HEALTH } \\
\text { PRESERVATION }\end{array}$ \\
$\begin{array}{l}\text { Isolation of healthy people. Preservation, maintenance and } \\
\text { promotion of health. Treatment of patients, contribution to } \\
\text { their recovery. Medicines and drugs in the aspect of the } \\
\text { means of recovery/maintaining health. Restriction of human } \\
\text { rights and freedoms in connection with quarantine. The } \\
\text { repressive aspect with «justifying» rationalization (for a good } \\
\text { cause) }\end{array}$
\end{tabular}

\section{Results}

For the purpose of discourses quantification, a binary nominal scale was used in the dataset ( 1 - THERE IS DISCOURSE; 0 - NO DISCOURSE), regardless of the amount of corresponding text units (words) and compositional linguistic features of the discourse's textual manifestations. Statistically significant results of binary logistic regression are presented in Table 2. As we can see the inter-discourse relationships have been mostly negative $(\operatorname{Exp}(B)<1)$, i.e. the actualization of one discourse is accompanied by a statistically significant decrease in the probability of another (others) appearances in the text, which in practice means the factual exclusion of these discourses from the quarantine concept (Table 2). This feature determines the respective tendentiousness (biasing) of the quarantine concept semantics. 
Table 2. Binary logistic regression (dependent variables - discourses)

\begin{tabular}{|c|c|c|c|c|c|c|c|c|}
\hline \multicolumn{2}{|c|}{$\begin{array}{r}\text { Dependent variables } \\
\text { (discourses) }\end{array}$} & \multirow{2}{*}{\multicolumn{2}{|c|}{ 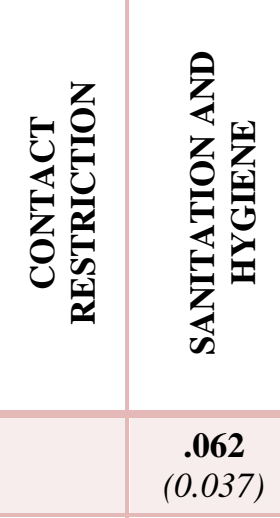 }} & \multirow[t]{2}{*}{ 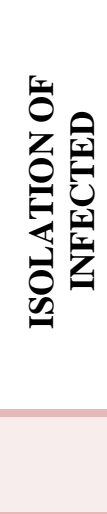 } & \multirow[t]{2}{*}{ 党芯 } & \multirow[t]{2}{*}{ 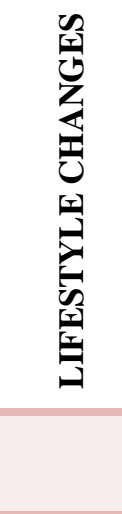 } & \multirow{2}{*}{ 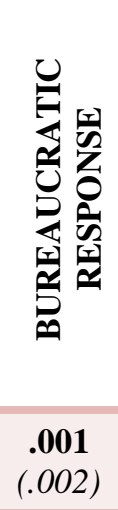 } & \multirow[t]{2}{*}{ 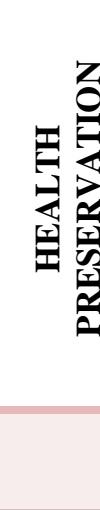 } \\
\hline CONTACT RESTRICTION & \multirow{10}{*}{ 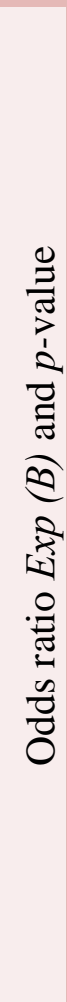 } & & & & & & & \\
\hline $\begin{array}{l}\text { SANITATION AND } \\
\text { HYGIENE }\end{array}$ & & & & & $\begin{array}{c}.001 \\
(.000)\end{array}$ & & & \\
\hline ISOLATION OF INFECTED & & & & & $\begin{array}{l}.066 \\
(.005)\end{array}$ & & $\begin{array}{l}.013 \\
(.006)\end{array}$ & \\
\hline VIRUS DISSEMINATION & & $\begin{array}{l}.052 \\
(.006)\end{array}$ & $\begin{array}{l}.003 \\
(.001)\end{array}$ & & & $\begin{array}{l}. \mathbf{0 2 8} \\
(.002)\end{array}$ & $\begin{array}{c}.032 \\
(.008)\end{array}$ & \\
\hline $\begin{array}{l}\text { LIFESTYLE } \\
\text { CHANGES }\end{array}$ & & & & & & & & \\
\hline $\begin{array}{l}\text { BUREAUCRATIC } \\
\text { RESPONSE }\end{array}$ & & $\begin{array}{l}.002 \\
(.001)\end{array}$ & & & & & & \\
\hline HEALTH PRESERVATION & & $\begin{array}{l}.022 \\
(.010)\end{array}$ & & & $\begin{array}{l}.064 \\
(.003)\end{array}$ & $\begin{array}{l}.029 \\
(.012)\end{array}$ & $\begin{array}{l}.007 \\
(.003)\end{array}$ & \\
\hline Number of discourses & & $\begin{array}{c}\mathbf{9 8 . 1 1 6} \\
(.000)\end{array}$ & $\begin{array}{c}\mathbf{2 4 . 9 4 2} \\
(.000)\end{array}$ & & $\begin{array}{c}\mathbf{2 2 . 2 7 6} \\
(.000)\end{array}$ & $\begin{array}{l}\mathbf{9 . 2 3 3} \\
(.012)\end{array}$ & $\begin{array}{c}\mathbf{9 5 . 6 7 0} \\
(.000)\end{array}$ & \\
\hline $\begin{array}{l}\text { Changes in everyday } \\
\text { life }\end{array}$ & & $\begin{array}{l}\mathbf{5 . 9 7 2} \\
(.006)\end{array}$ & & $\begin{array}{l}.404 \\
(.049)\end{array}$ & & & & \\
\hline Self-isolation (days) & & & & & & & & $\begin{array}{l}\mathbf{1 . 0 6 6} \\
(.050)\end{array}$ \\
\hline \multicolumn{2}{|l|}{${ }^{(*)}$ Model coefficient, $\chi^{2}($ sig. $p)$} & $\begin{array}{l}50.702 \\
(.000)\end{array}$ & $\begin{array}{l}38.625 \\
(.000)\end{array}$ & $\begin{array}{l}4.386 \\
(.036)\end{array}$ & $\begin{array}{l}51.613 \\
(.000)\end{array}$ & $\begin{array}{l}40.662 \\
(.000)\end{array}$ & $\begin{array}{l}53.023 \\
(.000)\end{array}$ & $\begin{array}{l}6.550 \\
(.010)\end{array}$ \\
\hline \multicolumn{2}{|c|}{$\begin{array}{l}{ }^{(* *)} \text { Model Summary (Nagelkerke R } \\
\text { Square) }\end{array}$} & .648 & .599 & .078 & .603 & .564 & .686 & .109 \\
\hline \multicolumn{2}{|l|}{$\begin{array}{l}{ }^{(* * *)} \text { Predictive value (overall \% } \\
\text { correct) }\end{array}$} & $86.0 \%$ & $90.7 \%$ & $80.2 \%$ & $82.6 \%$ & $86.7 \%$ & $88.4 \%$ & $79.1 \%$ \\
\hline
\end{tabular}

Above outlined inter-discourse connections impart to the discursive field a specific organization, which allows to consider the field as a discursive formation (Fig. 1). In the proposed scheme, the blue lines indicate negative inter-discourse connections and corresponding arrows point out on deactualized discourses. Note that there have been two pairs of discourses with two-way blue arrows: VIRUS DISSEMINATION and SANITATION AND HYGIENE, as well as BUREAUCRATIC RESPONSE and CONTACT RESTRICTION. The bilateral nature of negative connection, in our opinion, indicates of 
accented opposition-like relations between the respective discourses. On the other hand, returning to the identified features of the NUMBER OF DISCOURSE predictor, one cannot help but assume the existence of an association-like connection (red arrows on. Fig. 1).

This, at first glance, creates a contradiction - negatively connected discourses are simultaneously related associatively, i.e. in positive way. This paradox can be resolved by a systemic distinction of layers (semantic spaces), where the indicated negativity and positivity have taken place. The horizontal layer is represented by the functional interaction of discourses as structural components of the system. Note that at this level, the system also includes non-discursive factors (indicated in italics, Fig. 1). The vertical layer is formed through the meaning contribution by each discourse to the semantics of the quarantine concept as a supersystem. Thus, horizontal inter-discourse negative relations do not prevent the formation of positive connections - vertically integrated associations that are formed indirectly through the category of the supersystem (quarantine).

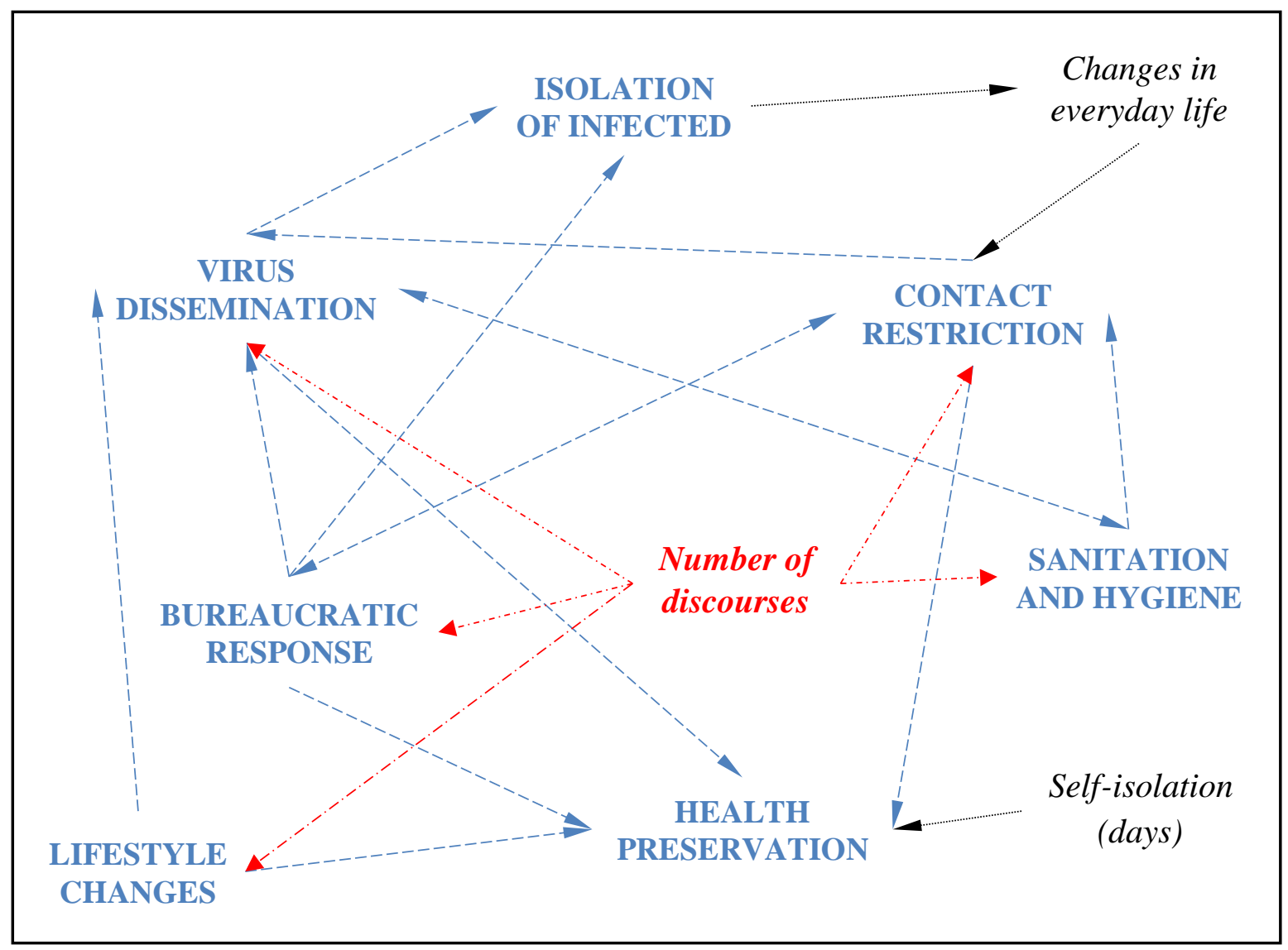

Fig. 1. The structure of the discursive formation of the quarantine concept 


\section{Conclusions}

We believe that the proposed view on quarantine might have a potentially useful applicability. For example, when conducting mass alerts of citizens, organizing educational communication of health authorities with the local population, introducing a quarantine regime at enterprises and institutions, etc., it is important to consider that the rhetoric about controlling of the virus spreading automatically deactivates the topic of sanitary and hygienic measures. Obviously, discursive semantics is associated with cognitive focus, which, in turn, affects the direction and consequences of proper behavior. Therefore, considering the structural and semantic features of the discursive formation in above cases could help increase the productivity and effectiveness of informational anti-epidemiological policies.

\section{References}

Foucault, M. (1972). Archaeology of knowledge and the discourse on language. New York: Pantheon.

Shymko, V. (2018). In Pursuit of the Functional Definition of a Mind: the Pivotal Role of a Discourse. Psycholinguistics, 24(1), 403-424. https://doi.org/10.31470/2309-1797-2018-24-1-403-424

Shymko, V. \& Babadzhanova, A. (2020). Study of the COVID-19 related quarantine notion as the language consciousness category on the sample of Russian speaking Ukrainians. Harvard Dataverse. https://doi.org/10.7910/DVN/Y2YGH7

Quarantine. (2020, July 13). Retrieved July 14, 2020, from https://en.wikipedia.org/wiki/Quarantine 